\title{
REPRESENTASI BUDAYA DALAM FILM SALAWAKU
}

\author{
Cindenia Puspasari ${ }^{1)}$, Masriadi ${ }^{1)}$, Rahmah Yani ${ }^{1)}$ \\ ${ }^{1)}$ Program Studi Ilmu Komunikasi, Universitas Malikussaleh \\ email:hmhyn258@gmail.com
}

\begin{abstract}
ABSTRAK
Film merupakan bentuk karya seni yang berisi informasi, dan hiburan, serta mengandung representasi atau pemaknaan terhadap sesuatu yang ditampilkan. Skripsi ini bertujuan untuk mengrepresentasi atau memaknai budaya lokal Maluku dalam Film Salawaku, yang merepresentasikan mengenai budaya pariwisata Provinsi Maluku dengan subjek penelitian yang meliputi adegan dan teks dialog dalam film Salawaku. Jenis pendekatan penelitian dalam skripsi ini menggunakan kualitatif dengan teknik analisis kandungan berdasarkan model budaya menurut Edgar H. Schein, yang mengkategorikan model budaya menjadi dua yaitu budaya benda dan budaya bukan benda. Hasil penelitian skripsi ini menunjukkan bahwa dalam Film Salawaku ditemukan representasi dua tanda kebudayaan antara lain budaya benda yang terdiri dari : (a) Seni Budaya (b) Bahasa (c) Produk Makanan dan Minuman Lokal(Pappeda dan Sopi) dan budaya bukan benda, yaitu : (a) Kepercayaan/Upacara Adat (b) Hubungan Personal..
\end{abstract}

Kata kunci : representasi film, schein model budaya, kebudayaan maluku, film salawaku

\section{PENDAHULUAN}

Film merupakan salah satu bentuk media komunikasi yang muncul dari produk media massa populer. Penyampaian pesan oleh film adalah cara yang cukup efektif agar penonton dapat mengetahui informasi yang ingin disampaikan oleh sutradara. Tampilan suara dan gambar dalam film ialah bentuk hasil yang mengandung unsur hiburan, kebudayaan, dan informasi sekaligus keberadaan film tersebut, yang dapat digunakan menjadi sarana sosialisasi politik, budaya, pendidikan, keindahan alam, maupun keagamaan.

Film merupakan salah satu produk komunikasi massa yang pengaruhnya mampu menjangkau seluruh segmen sosial masyarakat. Film dapat merepresentasikan sebuah kebudayaan dan berfungsi sebagai proses budaya suatu masyarakat yang disajikan dalam bentuk gambar bergerak. Pembuatan film tentunya dipengaruhi juga oleh latar belakang dan budaya dari para pembuatnya. (Ardianto,2004 : 136). Dalam hal ini, suatu budaya tertentu dipengaruhi oleh aksi 
media melalui penyebaran informasi yang ditampilkan. Disini, media punya peran yang vital karena menyajikan sebuah cara dalam mengkronstuksi sebuah realita. Isi dalam sebuah film digerakkan oleh para produser untuk merepresentasikan sebuah tanda-tanda maupun elemen suatu budaya. Salah satu film karya sineas Indonesia yang menampilkan suatu budaya dengan kearifan lokalnya adalah film berjudul Salawaku. Film ini bergenre road movie yang menghadirkan begitu banyak pesona alam dan kearifan budaya lokal khas Maluku yang diisi dengan sedikit kisah tentang hamil diluar nikah. Namun pada penelitian ini, isu hamil diluar nikah tidak dibahas terlalu spesifik, penulis hanya fokus pada sudut pandang budaya yang ada dalam film Salawaku.

Film Salawaku adalah sebuah karya perdana Pritagita Arianegara yang ditayangkan pertama kali dalam ajang tahunan Tokyo International Film Festival 2016 dengan menampilkan pertunjukkan keindahan alam yang begitu khas pada tiap pengambilan lokasi di daerah Maluku yang menjadi lokasi pembuatan film dan sekaligus mengajak kita lebih dekat mengenal karakter masyarakat Maluku. Walaupun film ini sempat ditolak di beberapa bioskop dalam negeri karena menyangkut nama sutradara Pritagita yang belum terlalu dikenal publik, namun tak dipungkiri bahwa film Salawaku menjadi media promosi wisata yang berbeda sekaligus cerdas karena tidak seperti sedang berjualan sebuah produk dibuktikan dengan tidak adanya iklan yang sering kali bermunculan dalam film dengan orientasi komersil.

Film ini menarik untuk diteliti karena memperlihatkan pertemuan dua latar belakang budaya yang sangat berbeda dari berbagai segi namun begitu indah dan menyenangkan saat bertemu dengan pengangkatan nuansa keindahan alam khas Maluku ditambah dengan sedikit konflik mengenai permasalahan hidup perempuan. Terlihat cover film Salawaku pun didominasi oleh panorama alamnya yang begitu khas. Asumsi dari film Salawaku begitu sederhana yaitu mencari keberadaan Binaiya, namun proses perjalanan Salawaku dapat membawa kita pada pengalaman yang bebeda dan dipadukan dengan sajian tampilan panorama alam yang begitu menakjubkan. 
Film sebagai bentuk representasi dari suatu budaya yaitu tentang bagaimana budaya tersebut ditampilkan juga tidak terlepas dari pengaruh dan nilai-nilai yang dianut oleh sutradaranya serta dipercayai oleh masyarakat yang diceritakan. Representasi dapat dilakukan dengan melihat pada model budaya yang dikemukakan oleh Schein, yang mengkategorikan budaya menjadi dua, yaitu budaya benda dan budaya bukan benda. Budaya benda, berdasarkan ciri-ciri yang digunakan oleh Schein, ialah budaya yang boleh dilihat atau didengar (visible and audible pattern), seperti setting, pakaian, peralatan keseharian, kendaraan, bahasa dan seni dan budaya. Sedangkan budaya bukan benda ialah budaya yang bersifat abstrak namun wujud dalam kehidupan masyarakat. Yang termasuk dalam kategori ini adalah hubungan personal, aspek komunikasi, nilai-nilai dan norma, agama dan kepercayaan, serta tingkah laku dan gaya hidup

Dalam penelitian ini, yang menjadi fokus penelitian ialah : (1) Identifikasi budaya Maluku dalam Film Salawaku. (2) Analisis budaya benda dan budaya bukan benda menurut Edgar H. Schein : Budaya benda (setting, media komunikasi, bahasa) \& budaya bukan benda (agama/ritus kepercayaan). Sedangkan rumusan masalah dalam penelitian ini adalah bagaimana budaya Maluku direpresentasikan ke dalam Film Salawaku dan rumusan masalah dalam penelitian ini adalah bagaimana budaya Maluku direpresentasikan ke dalam Film Salawaku. Berdasarkan judul penelitian penulis yaitu Representasi Budaya Maluku Dalam Film Salawaku, merupakan judul yang belum pernah dibahas oleh penulis sebelumnya.

\section{LANDASAN TEORI}

Menurut Prof. kuntjaraningrat, ada 3 wujud kebudayaan, yaitu : (1) Wujud kebudayaan sebagai suatu kompleks dariide-ide, gagasan-gagasan, norma-norma, peraturan dan sebagainya yang bersifat abstrak, tidak dapat diamati secara kasat mata, (2) Wujud kebudayaan sebagai suatu Kompleks aktivitas kelakuan berpola dari manusia dalam masyarakatnya. Wujud ini sering disebut sebagai sistem sosial. Dalam sistem sosial tersebut terdapat aktivitas manusia yang berinteraksi, serta saling mempengaruhi dari waktu ke waktu dan mengikuti pola-pola tertentu 
berdasarkan adat istiadat, (3) Wujud kebudayaan sebagai benda-benda hasil karya manusia atau kebudayaan fisik yang sifatnya paling konkret, dapat dilihat, dirasakan dan diamati. Dari hasil karya manusia mulai dari yang sederhana sampai yang paling rumit, misalnya dari korek api kayu sampai teknologi komputer. (Setiadi. dkk, 2011:28-30)

Kebudayaan yang dimiliki oleh setiap masyarakat tidak sama, seperti di Indonesia yang terdiri dari berbagai macam suku bangsa yang berbeda. Tetapi setiap kebudayaan mempunyai ciri atau sifat yang sama. Sifat tersebut bukan diartikan secara spesifik melainkan universal tanpa membedakan faktor ras, lingkungan alam ataupun pendidikan. Yaitu sifat hakiki yang berlaku umum bagi semua budaya di manapun, antara lain yaitu : (1) budaya terwujud dan tersalurkan dari perilaku manusia, (2) budaya telah ada terlebih dahulu daripada lahirnya suatu generasi tertentu dan tidak akan mati dengan habisnya usia generasi yang bersangkutan, (3) budaya diperlukan oleh manusia dan diwujudkan dalam tingkah lakunya, (4) aturan-aturan yang berisikan kewajiban, tindakan yang diterima dan ditolak, tindakan yang dilarang dan tindakan yang diizinkan. (Setiadi. dkk, 2011:33-34)

Sistem kebudayaan suatu daerah dapat menghasilkan jenis-jenis kebudayaan yang berbeda. Jenis kebudayaan ini dapat dikelompokkan menjadi dua jenis yaitu pertama, kebudayaan material yang berupa hasil cipta, karsa, yang berwujud benda, barang alat pengolahan alam seperti gedung, pabrik, jalan, rumah dan sebagainya. Kedua, kebudayaan non material yang berwujud kebiasaan, adat istiadat ilmu pengetahuan dan sebagainya. (Setiadi. dkk, 2011:33-35) Selanjutnya, Lustig \& Koester (Puspasari, 2017:03) menerangkan bahwa identitas budaya adalah sebagai rasa yang dimiliki seseorang terhadap sebuah budaya atau kumpulan etnis tertentu. Identitas budaya terbentuk dalam proses budaya yang meliputi pembelajaran dan penerimaan tradisi, warisan, bahasa, agama, keturunan, estetika, pola pikir dan struktur sosial dalam budaya. Seseorang yang memiliki identitas budaya menginternalisasikan kepercayaan, nilai, norma dan tingkah laku sosialyang berasal dari budaya mereka dan mengidentifikasikan budaya tersebut sebagai bagian dari konsep diri. 


\section{Model Budaya Edgar H. Schein}

Menurut Edgar H. Schein (Miller, 2006: 89) mendefinisikan budaya sebagai berikut,

"Culture is "A pattern of share basic assumption that the group learner as it solved itsproblems of external adaptation and internal integration, that has worked well enough to be considered valid and therefore, to be taught to new members as the correct way to perceive, think and feel in relation to these problems".

Ini berarti bahwa budaya ialah pola asumsi-asumsi yang ditemukan oleh suatu kelompok tertentu dan dikembangkan melalui pembelajaran untuk memecahkan masalah-masalah adatasi eksternal, dan integrasi internal yang telah berjalan cukup lama untuk dipandang sebagai sesuatu yang sahih, maka dari itu, diajarkan kembali kepada anggota-anggota yang baru sebagai cara yang benar untuk memandang, berpikir, dan merasa dalam kaitannya dengan masalah tersebut.

Menurut Schein, budaya organisasi mengacu pada suatu sistem makna bersama yang dianut oleh anggotanya untuk mengklasifikasikan organisasi tersebut terhadap organisasi lain. Schein juga menjelaskan beberapa unsur-unsur budaya, yaitu: ilmu pengetahuan, kepercayaan, seni, moral, hukum, adat-istiadat, perilaku, (norma) masyarakat, asumsi dasar, sistem nilai, pembelajaran/pewarisan, maupun masalah adaptasi eksternal dan integrasi internal.

Merujuk pada model budaya yang dipaparkan oleh Schein (Puspasari dkk, 2017:04) budaya dapat di bedakan menjadi dua jenis yakni budaya benda dan budaya bukan benda. Budaya benda memiliki ciri yaitu budaya yang bisa didengar atau dilihat seperti bahasa, pakaian, kendaraan, seni budaya, setting, peralatan keseharian dan budaya bukan benda adalah budaya yang sifatnya abstrak tetapi hadir secara nyata di kehidupan masyarakat seperti, nilai-nilai dan norma, agama, kepercayan, aspek komunikasi, tingkah laku maupun gaya hidup.

\section{Budaya Maluku}

Film Salawaku kental dengan tema lokalitas dan kearifan lokalnya, tidak hanya sekedar membuat promosi Indonesia karena mengangkat sektor-sektor wisata alam yang luar biasa di daerah Maluku, namun juga mengenalkan kebudayaannya, penggunaan bahasa daerah Maluku yang kenal, pengenalan 
karakter masyarakatnya, filosofi produk makanan atau minuman seperti Pappeda dan Sopi, serta makna seni tari dan filosofinya yaitu seni tari Cakelele dan arti pedang Salawaku. (Argadia, 2016:6)

Penggunaan bahasa daaerah yang kental menambah suasana kearifanlokal dalam film, karakter masyarakat beretnis Ambon, Maluku yang punya julukan pribahasa 'Labu Jua Ada Hati' yang jika diterjemahkan dalam bahasa indonesia adalah "sekeras-kerasnya watak orang Ambon, punya hati tetap lembut" hadir dalam film. Berdasarkan dari segi berbicara, terlihat tegas dan kasar namun dibalik itu, mereka tetap manusia biasa yang mempunyai hati nurani dan punya kekurangan.

Selain itu, sagu merupakan sumber makanan rakyat yang sudah lama dikenal oleh masyarakat yang daerahnya merupakan penghasil sagu. Olahan makanan yang terbuat dari sagu dengan cara pengolahannya maupun resepnya berasal dari kebiasan dan tradisi masyarakat yang diturunkan secara lisan dari turun-temurun. Subtansinya adalah sagu merupakan makanan rakyat sebagai informasi budaya karena bersifat sederhana (penyajiannya apa adanya). (Tulalessy, 2016:90).

Pemanfaatan sagu secara tradisi sudah lama dikenal di daerah-daerah penghasil sagu. Produk-produk makanan secara tradisi yang dihasilkan dari sagu seperti papeda, sagu lempeng, sagu bakar kelapa, sagu bakar apatar, dan lain sebagainya merupakan produk yang benar-benar terlahir dari sebuah pengetahuan tradisi masyarakatnya. (Tulalessy, 2016:87)

Selain memperkenalkan makanan lokal khas, minuman tradisional Maluku, yang dikenal dengan nama Sopi juga tak luput dari pembahasan. Soipi merupakan citra yang terwujud dalam semangat persaudaraan, dan telah berakar dalam kehidupan masyarakat. Sopi merupakan hikmat dari Tuhan bagi para leluhur masyarakat Maluku, untuk membuat minuman tradisional tersebut, dan sebenarnya merupakan simbol adat di Maluku. (Zairin, 2019)

Yang terakhir, yaitu filosofi tombak dan anak laki-laki, karena tombak dan panah telah menyatu denganpribadi laki-laki suku Nuaulu di Pulau Seram, Pewarisan nilai-nilai budaya yang terdapat pada tombak dan panah dilakukan 
sejak anak laki-laki masih berusia muda. Pada usia 5-6 tahun anak laki-laki sudah diperkenalkan dengan kedua senjata ini. Mulai dari cara memegangnya, menimbang-nimbangnya sampai akhirnya ia memiliki kemampuan dan keterampilan menggunakannya. (Fahham, 2016:27-28). Laki-laki dalam kehidupan sosial-budaya masyarakat suku Nuaulu di Pulau Seram memiliki kedudukan yang penting. Anak laki-laki sejak kecil telah ditempa sehingga ketika mereka dewasa, mampu bertindak sebagai pria yang bertanggung jawab baik terhadap dirinya sendiri maupun pada sesama. Kedewasaan seorang laki-laki ditentukan berdasarkan kemampuannya menggunakan senjata, panah dan tombak.

\section{Sinopsis Film Salawaku}

Dikutip dari laman web BookMyShow Indonesia (2017) film Salawaku ialah suatu karya sineas Indonesia yang bengenre drama (road movie). Film ini disutradarai Pritagita Arianegara dan dua orang produser yakni Ray Zuham dan Michael Julius dan penulis skenario bernama Iqbal Fadly dan Titien Watimena. Film Salawaku diperankan beberapa tokoh penting yaitu Karina Salim sebagai saras, Raihaanun sebagai Binaiya, Elko Kastanya sebagai Salawaku, J-Flow sebagai Kawanua, dan Shafira Umm. Film yang diproduksi Kamala Films ini rilis dan tayang pertama kali di ajang tahunan Tokyo International Film Festival 2016. Film ini mengangkat dan mengeksplorasi habis-hadapatn keindahan alam yang ada di Indonesia bagian Timur, yaitu Kabupaten Seram Bagian Barat, Maluku. Film Salawaku berkisah tentang dua orang bernama Salawaku dan Saras dimana dua karakter ini mempunyai perbedaan usia, budaya, sifat, kepentingan antar satu sama lain. Film dengan tema lokalitas dan kearifan lokal yang kuat.

Tekad kuat Salawaku, seorang bocah laki-laki tanggung asal Maluku, untuk mencari 'ussi'(panggilan kakak perempuan dalam bahasa Maluku) bernama Binaiya yang melarikan diri meninggalkan desa, terbentur dengan pertemuannya dengan Saras, seorang remaja perempuan asal Ibukota Jakarta yang memilih daerah Maluku untuk berlibur dan mengalihkan sejenak permasalahannya bersama kekasihnya. Saras yang terdampar disuatu pulau pasir di tengah laut awalnya membuat Salawaku dengan berat hati harus menolongnya. Seiring berjalannya cerita dalam perjalanan mereka 
ini lantas terjadi suatu hubungan yang saling bertolak belakang budaya, cara hidup dan kebiasaan dari tokoh Salawaku dan tokoh Saras. Hingga muncul masalah lain ketika Kawanua yang menyusul Salawaku yang tampak baik hati menawarkan bantuan untuk Salawaku agar menemukan Binaiya. Lantas, Salawaku mau menerima Kawanua untuk bergabung dalam perjalanan mereka karena telanjur percaya pada kakak angkatnya tersebut. Namun, kebaikan Kawanua yang sebenarnya mempunyai maksud lain untuk mencegah dan mengurungkan niat Salawaku bertemu dengan Binaiya karena pada dasarnya Kawanua lah yang menyebabkan Binaiya melarikan diri dari desa. Akan tetapi, mata Saras dan Salawaku akhirnya berhasil dibutakan oleh kebaikan Kawanua. Saras sedikit demi sedikit mulai melupakan patah hati terhadap kekasihnya di Jakarta dan mengalihkan hatinya pada Kawanua. Hingga pada satu titik Salawaku sadar bahwa mereka sebanarnya telah menjauhi daerah Piru, dimana dikabarkan Binaiya berada disana.

Film ini mencoba menaruh pesan tentang selalu ada pilihan dalam hidup melalui peristiwa didalamnya. Permasalahan yang sering terjadi di lingkungan masyarakat kita dan memunculkan konflik batin. Norma yang berbenturan serta bagaimana menjaga martabat sebuah keluarga. Ayah Kawanua adalah seorang Upulatu (orang terhormat di kampung) maka menjaga nama baik adalah keharusan. Hanya saja ada kesalahan yang dibuat oleh Kawanua dimana melibatkan Binaya sehingga Binaya harus pergi dan sembunyi di Piru. Melalui film Salawaku, Pritagita mencoba menampilkan kekayaan alam Indonesia di Maluku, di sisipkan dengan nuansa kearifan lokalnya dengan didominasi oleh bahasa dan dialek Ambon, Maluku. Film Salawaku juga mengajak penonton melihat kuliner yang begitu menggoda dari wilayah Timur sana. Ada Sopi (minuman khas Maluku yang mengandung alkohol). Penonton juga dapat mengenal Papeda (makanan unik khas Maluku yang terbuat dari tepung sagu), mengenal karakter etnis Ambon, dan filosofi Salawaku tercermin dari karakter tokohnya. 


\section{METODE PENELITIAN}

Jenis penelitian yang dilakukan yaitu secara kualitatif dengan teknik analisis kandungan. Objek penelitian yang ada di dalam penelitian ini adalah sebuah film bergenre roadmovie atau film perjalanan berjudul "Salawaku". Film ini dipilih karena penelitian ini meneliti tentang bagaimana representasi budaya Maluku yang ada dalam film tersebut. Subjek penelitian ini meliputi shot/sequence/scene dan teks dialog yang terdapat dalam film Salawaku yang nantinya akan di screenshoot atau rekam layar. Dalam hal ini, sequence kita kenal seperti dalam suatu teater yaitu babak. Sumber data dalam suatu penelitian ialah bagian vital yang harus diperhatikan. Dalam penelitian ini sumber data yang dijadikan bahan referensi atau acuan adalah data primer dan data kepustakaan

\section{HASIL PENELITIAN DAN PEMBAHASAN}

\section{Representasi yang diamati pada Aspek Budaya Benda}

1. Seni Tari Cakalele

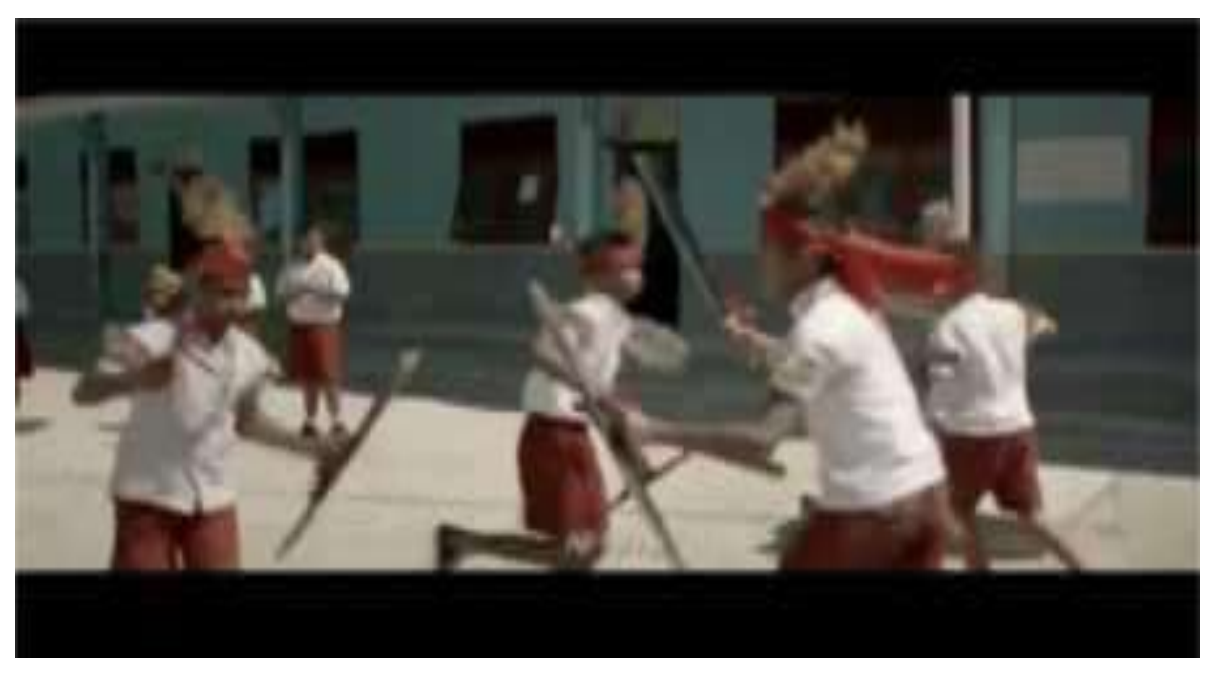

Representasi pada adegan tersebut adalah Salawaku seorang anak-anak asli Maluku dan melalui karakter Salawaku penulis melihat ketulusan dan kasih sayang seorang lelaki kecil yang begitu besar pada kakak perempuannya. Representasi penulis terkait nama Salawaku pada penokohan ditunjang dengan referensi lain yang bersangkutan yang mengatakan bahwa nama diri adalah sebuah simbol pertama dan utama bagi seseorang. 
Gambar diatas adalah adegan saat Salawaku beserta teman sekolahnya melakukan tarian Cakalele, Salawaku sudah melakukan perlawanan dan perjuangan harga dirinya dengan sang kakak yang dihina oleh teman-temannya lantas ia pun hampir melakukan tindakan kekerasan fisik berupa pukulan tangan pada temannya tersebut. Bukannya mendapatkan semangat motivasi dari lingkungan justru kalimat hinaan dan ejekan yang ia dapatkan disekolah. Namun, Salawaku adalah simbol kekuatan untuk keluarganya, terutama Binaiya seorang kakak perempuan seorang yang ia miliki di hidupnya, ia terus memperjuangkan keadilan untuk orang yang ia kasihi. Secara tidak langsung, diumur yang masih anak-anak Salawaku belajar dewasa dan bijaksana dari permasalahan orang dewasa tentang bagaimana cara mereka menghadapi sebuah masalah. Belajar memahami bahwa kehidupan adalah tentang bagaimana manusia meninggalkan dan ditinggalkan.

\section{Bahasa Ambon \& Dialek Maluku}

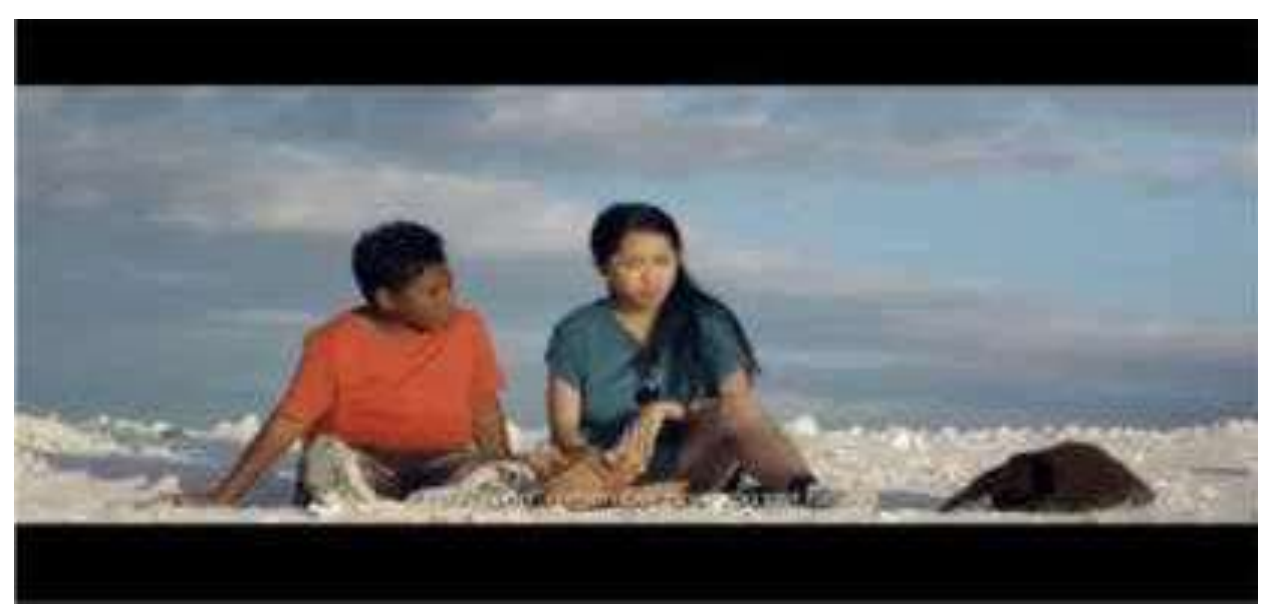

Gambar diatas merepresentasikan interaksi antara Saras dan Salawaku, yang kemudian membuat Saras bingung mendengar arti kata 'seng' yang diucapkan Salawaku kepadanya. Kata tersebut ialah salah satu bahasa daerah Ambon yang bermakna 'tidak'. Dalam hal ini, dapat ditafsirkan bahwa Salawaku sedang menunjukkan identitasnya sebagai orang Maluku dengan berinteraksi menggunakan dialek dan bahasa daerahnya. Bahasa adalah sarana berkomunikasi dan kemudian agar bahasa dapat dipahami pemakainya, maka pemberi dan penerima pesan dalam penggunaan bahasa harus mempunyai kesepakatan 
bersama dalam menggunakan simbol- simbol dan dalam mengrepresentasikan maknanya. Pada contoh prakteknya, konsep mengenai kata "seng" sebagai pengganti kata "tidak" akan bermakna ketika konteks budaya Maluku diperlakukan. Bagi penonton atau masyarakat yang asing dengan bahasa orang Maluku, konsep "seng" akan berbeda maknanya atau bahkan hampir sulit untuk dipahami karena bahasa Maluku tidak berlaku di luar masyarakat Maluku.

Dalam film, karakter Salawaku digambarkan dengan watak keras kepala ditambah dengan gaya berbicara yang keras. Di Indonesia, suku bangsa lain yang dikenal dengan penekanan suara yang keras adalah Suku Batak dan suku bangsa di Riau Kepulauan. Selain itu, bangsa yang cenderung bersuara keras saat berkomunikasi yaitu bangsa Arab, terutama ketika mereka berbicara kepada orang yang mereka sukai. Bagi orang Arab suara keras menandakan kekuatan dan ketulusan, sedangkan suara lemah mengisyaratkan kelemahan atau tipu daya. Maka dari itu bila kita tidak mengenal karakter budaya ini Ini kemungkinan kita menganggap suara keras mereka sebagai tanda agresivitas, kekasaran atau kemarahan bukan sebagai cerminan ketulusan atau keramahan.

Kesalahpahaman ini terjadi pada Saras selaku masyarakat diluar suku Ambon, yang menganggap Salawaku seperti 'preman' karena bersuara keras dan terkesan kasar saat berbicara dengannya. Bahkan anggapan Saras terhadap kesan 'jahat' pada orang Ambon sampai pada dugaannya bahwa ia mengira akan dibunuh oleh pemuda desa yang mencari Salawaku. Padahal kondisi tersebut dipicu karena Salawaku berasal dari daerah pesisir pantai,kepulauan Maluku yang masih dikelilingi oleh alam yang begitu luas dengan kondisi kerasnya tiupan angin dan ombak sehingga membuat Salawaku berbicara dengan dialek bergelombang, aksen yang tegas dan volume yang tinggi, kasar dan seperti 'preman' yang identik dengan kekerasan.

Secara umum yang terbangun didalam masyarakat adalah generalisasi, kebiasaan ataupun karakter orang-orang tertentu dalam mayarakat dijadikan sebagai sesuatu yang berlaku umum, untuk semua orang. Namun, diluar hal tersebut masih banyak masyarakat Ambon yang berbicara dengan gaya bahasa yang santun. Terlalu sulit untuk menyatakan satu bentuk karakter sebagai label 
untuk suatu suku, ada yang terlihat menonjol namun akan hadir orang-orang lain yang berasal dari suku yang sama namun tidak nyaman dengan label yang diberikan tersebut. Penulis melihat bahwa karakter Salawaku yang dihadirkan mampu memberikan contoh yang baik bagi para penonton, sebagai masyarakat dengan keberagaman suku telah memenuhi dasar-dasar etika sosial budaya yang merupakan ketentuan baik buruk yang bersumber dari nilai-nilai dan normanorma sosial budaya di masyarakat seperti bersikap baik terhadap orang lain, mempunyai rasa peduli karena membantu Saras dari masalahnya, serta memberikan perhatian kepada Saras yang mengalami luka di area kaki. Ia menganggap Saras layaknya seperti kakaknya sendiri, maka ia melakukan hal-hal baik kepada Saras

\section{Bahasa}

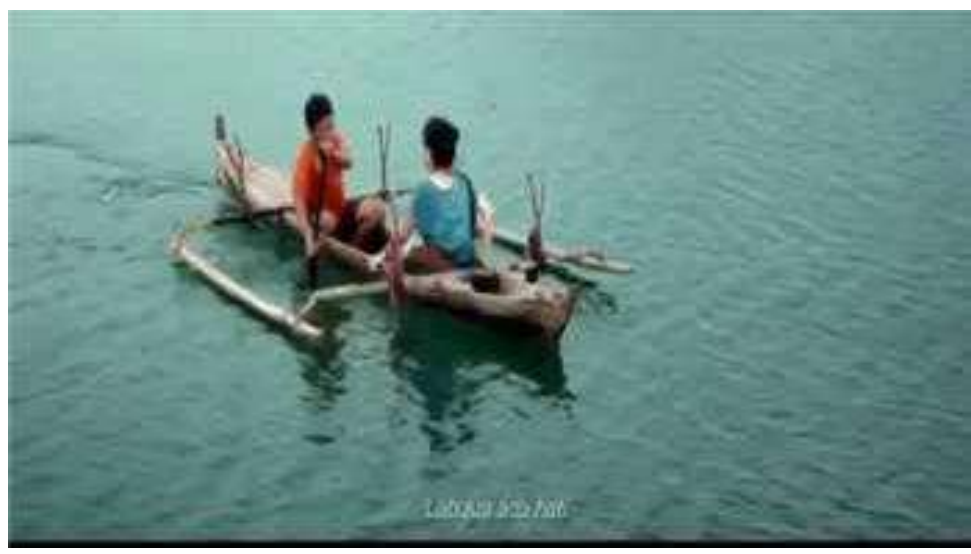

Pada gambar diatas ialah interaksi yang dilakukan Salawaku dan Saras di atas sampan atau perahu. Selepas terhindar dari pemuda desa yang mencari Salawaku, ia pun bertanya mengapa Saras terus mengikuti dirinya. Saras yang ketakutan langsung mengatakan bahwa ia takut diculik dan dibunuh oleh pemuda desa yang mencari Salawaku. Lantas, Salawaku menolak secara tegas bahwa masyarakat didesanya tidak mempunyai niat jahat seperti itu dengan mengungkapkan pribahasa

Nama dapat melambangkan status, cita rasa budaya, untuk memperoleh citra tertentu (pengelolaan kesan) sebagai nama hoki atau apapun alasannya. Nama pribadi adalah unsur penting identitas seseorang dalam masyarakat karena 
interaksi dimulai dengan nama dan kemudian diikuti dengan atribut lainnya. (Mulyana, 2005:274-275).

Karakter masyarakat beretnis Ambon, Maluku yang punya julukan pribahasa 'Labu Jua Ada Hati' yang jika diterjemahkan dalam bahasa indonesia adalah "sekeras-kerasnya watak orang Ambon, punya hati tetap lembut" disampaikan oleh Salawaku pada Saras. Berdasarkan karakter Salawaku yang masih berusia anak-anak, dari segi berbicara terlihat tegas dan kasar namun dibalik itu mereka tetap manusia biasa yang mempunyai hati nurani, rasa peduli dan punya kekurangan. Kepedulian Salawaku terbukti pada gambar diatas, yang akhirnya menolong Saras yang diceritakan terdampar di pulau seorang diri dan tidak tau harus kemana. Julukan ini pun tercermin dari prilaku Salawaku yang terus menolong Saras sebagai seseorang yang tidak pernah ia kenal sebelumnya, dari awal menemukan Saras terdampar disebuah pulau hingga melakukan perjalanan bersama-sama untuk saling menemukan tujuan. Kekuatan nilainilai maupun segala sumber daya sosial budaya membentuk dan mempengaruhi pola tingkah laku individu. Oleh karena setiap individu memiliki lingkungan sosial budaya yang berbeda dengan yang lain maka situasi ini menghasilkan karakter sosial budaya setiap individu yang bersifat unik khusus dan berbeda dengan orang lain. (Aw, 2010:27)

\section{Representasi Makanan Khas - Pappeda}

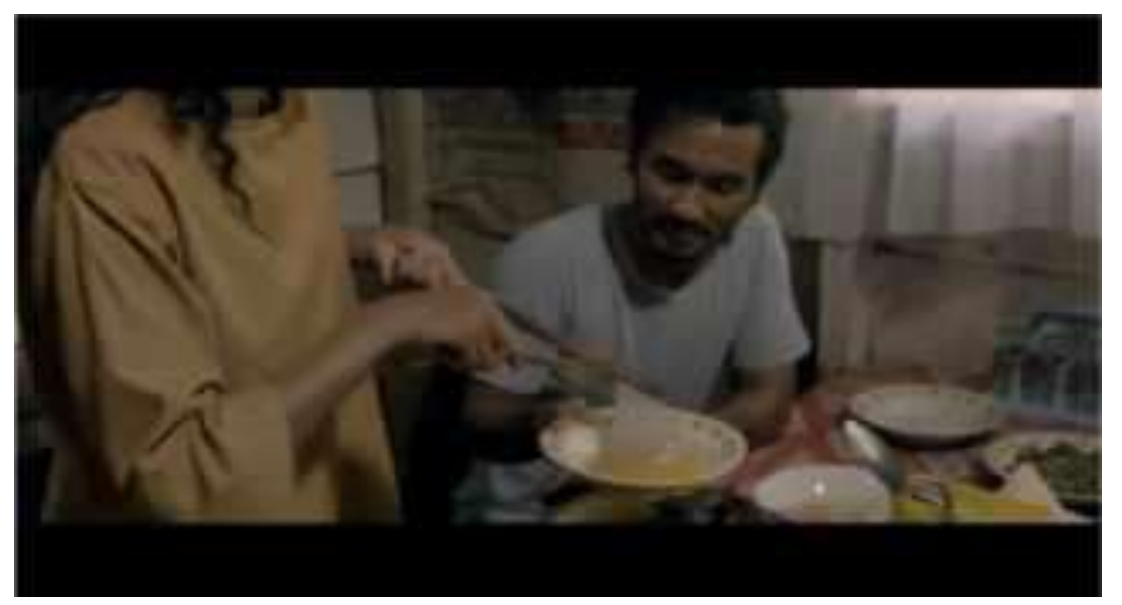

Dalam tradisi masyarakat Kampung Abar di Distrik Ebungfau, Kabupaten Jayapura, Papua, satu keluarga akan makan papeda dari satu "sempe" sebagai 
tanda ikatan kekeluargaan. Pada gambar diatas ialah adegan Binaiya yang sedang bercerita sedikit pada Saras tentang cara membuat Pappeda dengan sederhana dan filosofinya menurut orang Nusa Ina (Pulau Seram) yakni sebagai perekat hubungan antara keluarga, maupun teman-teman. Adegan yang menunujukkan ketiga tokoh mengkonsumsi Pappeda secara bersamaan, dapat dimaknai sebagai makanan ini menjadi media perekat hubungan antar saudara maupun teman, diceritakan Saras yang bertolak belakang dari segi budaya, cara hidup dan kebiasaan dengan Salawaku, Binaiya, dan Kawanua namun tetap hangat saat bertemu. Tidak membedakan ras, agama, dan suku, mereka tetap saling tolong menolong.

Sagu merupakan sumber makanan rakyat yang sudah lama dikenal oleh masyarakat yang daerahnya merupakan penghasil sagu. Olahan makanan yang terbuat dari sagu dengan cara pengolahannya maupun resepnya berasal dari kebiasan dan tradisi masyarakat yang diturunkan secara lisan dari turun-temurun. Subtansinya adalah sagu merupakan makanan rakyat sebagai informasi budaya karena bersifat sederhana (penyajiannya apa adanya). (Tulalessy, 2016:90)

\section{Representasi Minuman Khas - Sopi}

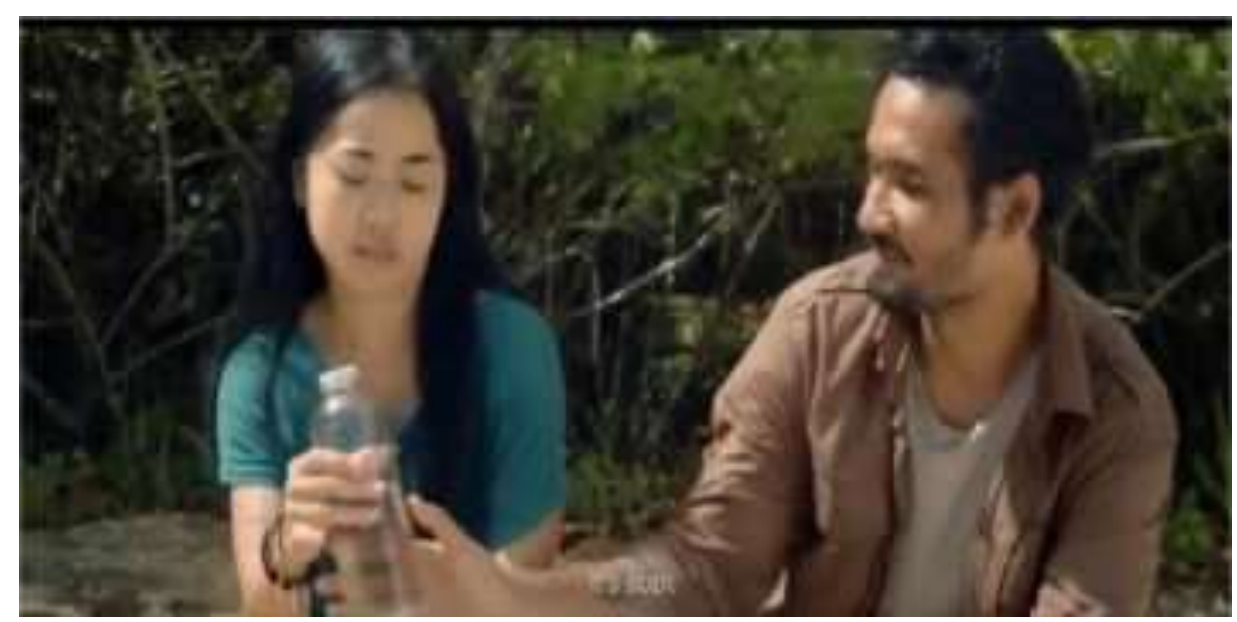

Sopi atau moke adalah sekian dari nama lokal untuk minuman khas yang diproduksi secara turun temurun oleh masyarakat yang ada di berbagai pulau di Nusa Tenggara Timur maupun Maluku. Sopi atau moke yang namanya bervariasi tergantung etnis penyebutnya merupakan atribut yang tidak terlepas dari setiap perayaan upacara tradisional. Meskipun memegang peranan penting dalam acara 
adat, tidak berarti minuman organik tradisional ini juga diterima dengan baik di berbagai kalangan di NTT. Selain penting dalam fungsi adat, secara ekonomis tidak dipungkiri bahwa arak organic tradisional memang menjadi sumber pendapatan bagi sekian keluarga yang memiliki tradisi penyulingan (destilasi) arak. (Li, 2013:01)

Wakil Gubernur Maluku, Barnabas Orno pernah mengatakan bahwa minuman tradisional Maluku, yang dikenal dengan nama Sopi, merupakan citra yang terwujud dalam semangat persaudaraan, dan telah berakar dalam kehidupan masyarakat. Ia melanjutkan bahwa Sopi merupakan hikmat dari Tuhan bagi para leluhur masyarakat Maluku, untuk membuat minuman tradisional tersebut, dan sebenarnya merupakan simbol adat di Maluku, juga dikatakan bahwa Sopi adalah produk yang membiayai hampir sebagian besar kehidupan di daerah-daerah di Maluku, hampir semua menjadi sentra produksi minuman tradisional ini, walaupun masih dikategorikan ilegal. Bukan sekedar untuk dikonsumsi para pemuda mabuk-mabukan, namun minuman tradisional ini sangat berarti dalam melaksanakan upacara adat atau pesta adat, dimana sopi sudah pasti menjadi harga mati. (Zairin, 2019)

Di Flores, Sopi menjadi salah satu konsumsi utama para lelaki Flores. Bukan mereka tak menyukai minuman keras lain, tapi dalam kultur mereka, Sopi dianggap sebagai minuman yang prestisius atau mewah, dan merupakan bagian dari ukuran martabat kehormatan tradisi adat warisan leluhur. Sopi disebut sebagai minuman kekeluargaan. Dikeluarkan saat acara adat maupun menyambut tamu. (Iman, 2018). Dalam film, Kawanua berstatus sebagai anak dari Upulatu (orang terhormat di kampung) maka dapat dimaknai dengan hadirnya Sopi itengah perjalanan Kawanua ialah untuk menunjukkan bahwa itu merupakan bagian dari kerhormatan tradisi adat dan sekaligus menyambut Saras di pulau Seram yang berstatus sebagai backpacker atau tamu di Pulau Seram. Representasi diatas diperkuat dengan ungkapan Fredy Frits Maunareng, selaku Ketua Komunitas Wetar Peduli, Tokoh Pemuda Wetardi laman RakyatMaluku.com pada tanggal 28 Mei 2019, bahwa pertemuan informal di rumah-rumah penduduk atau untuk menjamu tamu dirasa kurang lengkap jika tidak ada sopi. Bagi beberapa wilayah 
di Maluku yang memproduksi minuman ini, sopi dianggap sebagai pengganti kopi.

\section{Representasi pada Aspek Budaya Bukan Benda}

1. Representasi Kepercayaan Adat (Hubungkait Tombak dan Laki-Laki)
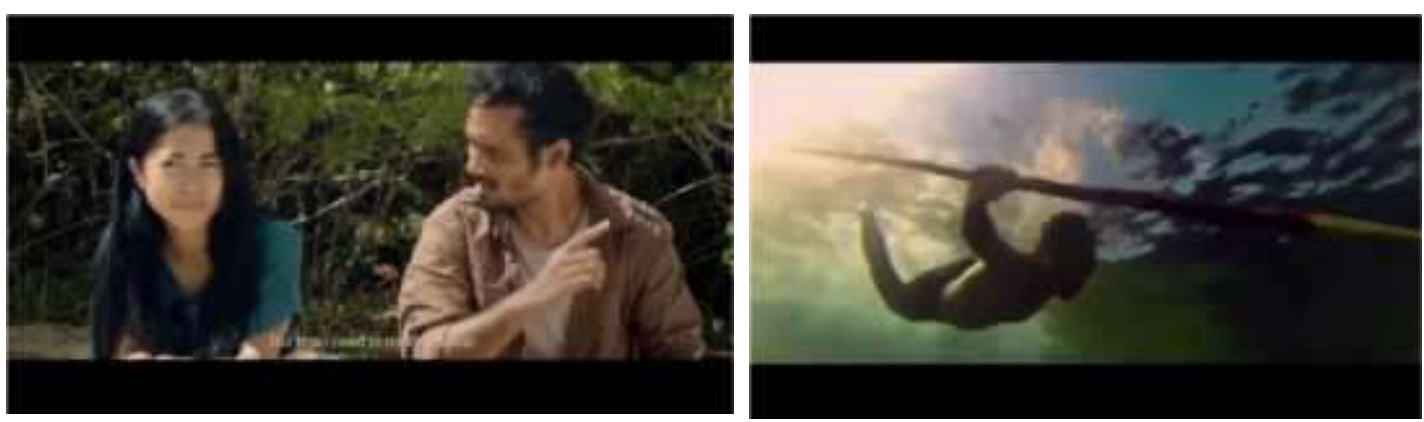

Gambar diatas menunjukkan bahwa menunjukkan bahwa Kawanua yang diceritakan sebagai pemuda asli Pulau Seram menunjukkan kecerdasannya dalam membuat tombak dan menyelam ke laut kepulauan Maluku untuk mencari ikan.Keahlian Kawanua pun turut diakui oleh Saras selaku pendatang dari kota lain yang memuji keahlian menyelamnya. Dalam referensi lain yang bersangkutan salah satunya penelitian A. Muchaddam Fahham mengatakan bahwa suku Nuaulu merupakan salah satu suku di Pulau Seram yang masih menganut sistem religi warisan leluhur mereka. Secara umum kehidupan suku Nuaulu diikat oleh sistem adat istiadat yang telah mereka warisi secara turun temurun. Adat istiadat itu mengatur pola hidup dan perilaku keseharian mereka. Dalam adat istiadat itulah ditemukan sistem keyakinan dan sistem ritus mereka (Fahham, 2016:21).

Masyarakat suku Nuaulu memiliki beragam ritus sebagai penghormatan mereka terhadap yang supranatural, roh dan roh leluhur. Beragam ritus itu antara lain adalah ritus kehamilan, kelahiran, menuju dewasa, perkawinan, dan kematian. (Fahham, 2016:24). Laki-laki dalam kehidupan sosial-budaya masyarakat suku Nuaulu memiliki kedudukan yang penting. Anak lakilaki sejak kecil telah ditempa sehingga ketika mereka dewasa, mampu bertindak sebagai pria yang bertanggung jawab baik terhadap dirinya sendiri maupun pada sesama. Kedewasaan seorang laki-laki ditentukan berdasarkan kemampuannya menggunakan senjata, panah dan 
tombak.Kelangsungan hidup masyarakat suku Nuaulu sangat ditentukan oleh ombak dan panah. Pada masa lalu, kedua alat ini berfungsi untuk berburu dan mempertahankan diri dari serangan musuh. Intinya, kemampuan dan ketrampilan laki-laki menggunakan tombak dan panah menjadi patokan utama dalam menentukan tingkat kedewasaan seorang laki-laki. Penelitian Fahham turut didukung oleh beberapa penelitian lain yang berkaitan. Misalnya dalam penelitian Utami (2015) yang mengatakan bahwa tombak dan panah telah menyatu dengan pribadi laki-laki suku Nuaulu, Pewarisan nilai-nilai budaya yang terdapat pada tombak dan panah dilakukan sejak anak laki-laki masih berusia muda. Pada usia 5-6 tahun anak laki-laki sudah diperkenalkan dengan kedua senjata ini. Mulai dari cara memegangnya, menimbang-nimbangnya sampai akhirnya ia memiliki kemampuan dan keterampilan menggunakannya. (Fahham, 2016:27-28).

Proses pewarisan nilai-nilai ini dilakukan secara langsung. Misalnya dengan mengikutsertakan sang anak dalam kegiatan berburu. Proses ini memakan waktu yang cukup lama selama beberapa tahun. Lamanya waktu yang diperlukan tidaklah sama bagi setiap anak, ada yang cepat tapi ada juga yang lambat, tergantung potensi sang anak. (Fahham, 2016:28)

Dalam scene yang sama juga dikatakan bahwa Salawaku mampu berenang dan mencari ikan dengan sangat cepat. Hal ini selaras dengan isi penelitian Utami dan Fahham yang sudah dijelaskan diatas bahwa pewarisan nilai-nilai budaya yang terdapat pada tombak dan panah dilakukan sejak anak laki-laki berusia 5-6 tahun hingga akhirnya ia mahir berenang dan menggunakan tombak untuk mencari ikan. Sementara itu, Kawanua sebagai laki-laki dewasa, sedang dipersiapkan untuk menjadi pemimpin adat ialah penduduk asli pulau Seram yang mempunyai rasa peduli terhadap orang lain terlebih peduli dengan citra dirinya dan ayahnya yang merupakan seorang pemuka adat setempat.

Namun di sisi lain, terdapat semacam "kecenderungan bias gender" yang secara diamdiam dilabelkan pada peran laki-laki dan perempuan di Maluku Tengah (Seram). Seperti ditemukan dalam ungkapan seperti ini, "Anak laki-laki pegang parang salawaku, Anak perempuan pegang sempe aru-aru". Sempe aru-aru adalah tempat untuk memasak papeda. Ini adalah simbol dari keterampilan 
memasak; sedangkan laki-laki dituntut terampil memainkan parang salawaku. Kualitas-kualitas tersebut dapat menentukan tingkat kedewasaan dan kematangan seseorang sebagai laki-laki dan perempuan, bahkan menentukan kesiapan untuk menikah. Seperti dalam ungkapan lainnya yang berbunyi : "Kalau belum sanggup pegang sempe dan aru-aru, jangan cepat terima lamaran pria", dan "kalau belum sanggup pegang parang salawaku, jangan melamar gadis orang" (depdikbud 1996/1997).

Pada gambar 4 diatas dalam representasi makanan khas budaya benda dari Maluku ialah adegan Binaiya yang sedang bercerita sedikit pada Saras tentang filosofi makanan Pappeda, bahwa menurut orang Nusa Ina (Pulau Seram) Pappeda dibuat sebagai perekat hubungan antara keluarga, maupun teman-teman. Hubungan personal yang diamati dalam film Salawaku ini dapat diibaratkan seperti filosofi Pappeda yaitu hubungan antara kakak dan adik yang menguat karena rasa kebersamaan (budaya kolektif) dalam hubungan kekeluargaan yang erat. Di dalam film Salawaku ini terlihat pada alur cerita Salawaku yang melakukan perjalanan jauh dalam mencari keberadaan sang kakak yang tiba-tiba pergi meninggalkannya. Disinilah terbentuk alur hubungan interpersonal antara kakak beradik. Tersirat bahwa ada kekuatan batin antara seorang kakak dan adik, yaitu antara Bianiya sebagai seorang kakak yang percaya pada adiknya seorang yaitu Salawaku. Kekuatan batin yang terbentuk dari seorang adik yang mengkhawatirkan kakaknya dan membuatnya ingin mencari kakaknya. Dan dialog budaya dengan sentuhan personal antara hubungan kakak dan anak ini, pada akhirnya menjawab segala permasalahan.

\section{KESIMPULAN}

Budaya menjadi aspek yang penting karena merupakan sebuah identitas yang menunjukkan karakter berbeda dari setiap masing-masing individu. Budaya adalah landasan jembatan komunikasi. Apabila budaya beraneka ragam, tentu praktik-praktik komunikasi yang dilakukan juga akan bermacam-macam. Berdasarkan hasil penelitian yang telah penulis lakukan, hasil representasi pada film Salawaku pada aspek budaya benda dan budaya bukan benda model budaya 
Schein yang telah dijelaskan di atas diperoleh kesimpulan. Pertama, budaya benda ialah budaya yang boleh dilihat atau didengar (visible and audible pattern) terdiri atas : (1) bahasa, (2) Seni Budaya (Tari Cakalele), (3) Produk makanan/minuman (Pappeda dan Sopi). Kedua, budaya bukan benda yaitu budaya yang abstrak namun hadir nyata dalam kehidupan masyarakat yaitu: (1) Kepercayaan/ritual adat dan (2) Hubungan interpersonal adalam alur cerita pencarian seorang adik terhadap sang kakak, disebabkan adanya kekuatan batin yang terjalin antara kakak beradik. Film Salawaku menjadi media promosi wisata, nilai budaya serta kebudayaan Maluku yang cerdas sekaligus berbeda, dengan tidak meletakkan iklan dengan tujuan komersil. Menyajikan pengenalan karakter orang Ambon, memperkenalkan makanan-makanan lokal khas Maluku, serta menampilkan tempat-tempat pariwisata yang eksotis. 


\section{DAFTAR PUSTAKA}

Ardianto, Elvinaro. (2004). Komunikasi Massa : Suatu Pengantar. Bandung : Simbiosa Rekatama Media

Argadia, Riva, dkk. (2016). Penyusunan Data Awal Referensi Nilai Budaya Tak Benda Kota

Ternate Provinsi Maluku Utara : Tarian Cakalele. Ternate : Kementrian Pendidikan dan Kebudayaan.

Aw, Suranto. (2010). Komunikasi Sosial Budaya. Yogyakarta : Graha Ilmu

Berger, Peter L. \& Thomas Luckmann 1990. Tafsir Sosial atas Kenyataan: Risalah tentang Sosiologi Pengetahuan (diterjemahkan dari buku asli The Social Construction of Reality oleh Hasan Basari). Jakarta: LP3ES.

Fahham, A Muchaddam. (2016). Sistem Religi Suku Nuaulu Di Pulau Seram Maluku Tengah.Jurnal Aspirasi Vol. 7, No. 1, Juni 2016. Jakarta:Pusat Penelitian Badan Keahlian DPR RI

Li, Dominggus Elcid. (2013). Industrialisasi Sopi di NTT Yang Berkelanjutan. Briefing Paper 001. www.irgsc.org

Miller, Katherine. (2006). Organizational Communication: Approaches and Processes (6th ed.). Belmont C/A. Thomson and Wadsworth.

Mulyana, Deddy (2005). Ilmu Komunikasi Suatu Pengantar. Bandung: PT. Remaja Rosdakarya

Puspasari, C, dkk. (2017). Pengaruh Globalisasi Dalam Film Indonesia: Representasi Budaya

Dalam Film Nagabonar dan Nagabonar Jadi 2. Cover Age 8:Journal Of Strategic Communication, Volume 8, No.1, September 2017. Universitas Pancasila

Tulalessy, D, Quin. (2016). Sagu Sebagai Makanan Rakyat dan Sumber Informasi Budaya Masyarakat Inanwatan : Kajian Folklor Non Lisan. Jurnal Ilmiah Kajian Sastra dan Bahasa : Melanesia, Volume 01, Nomor 01, Agustus 2016. UNIPA Manokwari

Iman, Mustafa. (2018). (https://lokadata.id/artikel/air-kekeluargaan-itu-bernamasopi) diakses tanggal 19 Agustus 2019 